\title{
Family, wealth, and governance: an agency account
}

Thomas Zellweger

University of St.Gallen, Center for Family Business

Dufourstrasse 40a

CH-9000 St.Gallen

thomas.zellweger@unisg.ch

$+41712247100$

\author{
Nadine Kammerlander \\ University of St.Gallen, Center for Family Business \\ Dufourstrasse 40a \\ CH-9000 St.Gallen \\ nadine.kammerlander@unisg.ch \\ +41712247116
}

February 2015

This is a preprint of an Article accepted for publication in Entrepreneurship Theory and Practice: (C) 2004 by Baylor University

Please cite as:

Zellweger, T. \& Kammerlander, N. forthcoming. Family, wealth, and governance: an agency account. Entrepreneurship Theory and Practice. 


\title{
Family, wealth, and governance: an agency account
}

\begin{abstract}
Family firms often evolve into ownership constellations with multiple family owners. Building on agency theory, we argue that the growing complexity within a group of family blockholders gives rise to what we label family blockholder conflicts, defined as conflicts within a group of family owners. To curb family blockholder conflicts, families often separate the family from its assets and install intermediary governance structures. We explore four frequently applied structures (uncoordinated family, embedded family office, single family office, and family trust), which vary in their degree of separation between family owners and assets and consequently the extent to which the firm might incur family blockholder costs and the double-agency costs associated with appointing agents to oversee agents. We conclude with a discussion of the distributive effects of the four family governance constellations for family wealth over time.
\end{abstract}

Keywords: family blockholder conflicts; double-agency costs; family office; trust; longevity

\section{INTRODUCTION}

Much of the extant family firm literature treats family firm owners as a unitary group of owners with shared interests that differ from those of nonfamily owners (e.g., Carney, 2005; Morck \& Yeung, 2003). This broad-brushed view of family firms, however, neglects the variety within the group of family firm owners. Such heterogeneity in part arises from the natural drift of families across generations and the resulting increase in the complexity of family ownership over time (Gersick, Davis, McCollom Hampton, \& Lansberg, 1997). In contrast to founder-controlled firms, many later-generation family firms are controlled by multiple family owners, and longlived family firms, such as the German Haniel group, founded in 1756, are sometimes controlled by several hundred family owners.

Multiple family owners likely differ in their financial and nonfinancial interests, leading to potential family feuds and conflict (Bertrand, Johnson, Samphantharak, \& Schoar, 2008; 
Eddleston \& Kellermanns, 2007). A closer look at the agency literature, which figures most prominently in explaining the governance of family firms (Anderson \& Reeb, 2003; Chrisman, Chua, \& Litz, 2003; Schulze, Lubatkin, Dino, \& Buchholtz, 2001), reveals that authors largely assume away the existence of heterogeneous interests, goals, and preferences among individual family owners and implicitly converge on a central assumption about family ownership: the family acts as a united group of owners and thus as a monolithic blockholder. Family sociologists, therapists, and advisors, however, provide striking accounts of the heterogeneous interests behind the façade of seemingly united families (Kets de Vries, 1993) and of the demand for family governance regulations to align these interests (Ward \& Aronoff, 2010).

The complexity arising from heterogeneous interests among multiple family owners creates a need for coordination among family member interests and hence mitigation of what we label family blockholder conflicts. One way for families to address these conflicts is to separate family owners from their (business) assets via the establishment of intermediary structures, such as family offices or family trusts (Dunn, 1980; Marcus \& Hall, 1992). But setting up such intermediary structures aimed at curbing family blockholder conflicts and related costs creates a double separation of ownership and control, which gives rise to double-agency costs (Carney, Gedajlovic, \& Strike, 2014). Double-agency costs arise if a first-tier agent, such as a family officer, trustee, or some other trusted advisor (Strike, 2013), is placed in an intermediary position between the principal and the second-tier agent (e.g., corporate manager).

By drawing on agency theory (Bertrand et al., 2008; Child \& Rodrigues, 2003; Chrisman, Chua, \& Litz, 2004; Jensen \& Meckling, 1976; La Porta, Lopez-de-Silanes, Shleifer, \& Vishny, 2000; Morck \& Yeung, 2003) and the law and economics literature on corporate and, more broadly, asset control (Carney et al., 2014; Claessens, Djankov, Fan, \& Lang, 2002; Dunn, 1980; Marcus \& Hall, 1992; Sitkoff, 2004; Zeitlin, 1974), we systematically study the agency costs 
associated with four frequently applied governance constellations aimed at mitigating family blockholder conflicts. We thereby aim to make three contributions to the literature. First, we acknowledge heterogeneous interests within the group of family owners and discuss family blockholder agency costs - a previously neglected type of agency costs unique to family firms. Second, we discuss four commonly observed family governance structures with different levels of separation between family and business (uncoordinated family, embedded family office, single family office, family trust). These governance structures vary in their ability to solve family blockholder conflicts and in their susceptibility to double-agency costs arising from the separation of the family from its wealth. Our findings suggest that future studies that investigate governance in family firms and in particular in complex structures such as family business groups (Carney, Gedajlovic, Heugens, Van Essen, \& Van Oosterhout, 2011; Gedajlovic, Carney, Chrisman, \& Kellermanns, 2012; Morck \& Yeung, 2003) should pay attention to those two types of agency costs. Third, our discussion of family governance structures and related agency costs advances the burgeoning debate on the longevity of family firms, the persistence and decline of family wealth, and the phenomenon of dead money (Carney et al., 2014) by adding a micro perspective, based on agency costs, to the previously discussed institutional factors.

\section{THEORETICAL FOUNDATIONS}

\section{Agency Theory and Family Firms}

In its classic form, agency theory postulates that managerial ownership should have a positive effect on the functioning of a corporation, as it naturally aligns the interests of owners and managers (Jensen \& Meckling, 1976). Building on this traditional view, it has been presumed that family involvement in both ownership and management should be particularly efficient in aligning the interests of principals and agents because of the benevolence inherent in familial relationships. However, a highly influential series of studies have called into question the absence 
of owner-manager agency conflicts when both owners and managers are embedded in the same family (Lubatkin, Lane, \& Schulze, 2001; Schulze et al., 2001). These studies broadly suggest that sanctioning inefficient family members (e.g., parents sanctioning their children) may be difficult because of the existence of altruistic family ties; thus, monitoring and incentive mechanisms are necessary even in family firms.

Scholars who focus on the role of blockholders rather than the relationship between owners and managers suggest that ownership concentration should generally benefit firms, because (family) blockholders have the economic incentives and power to monitor and sanction managerial mischief (Demsetz \& Lehn, 1985). This positive relationship between ownership concentration and agency costs is contested, however, as blockholders may use their unchallenged power to extract private benefits of control that serve their financial and nonfinancial interests but harm minority owners. This phenomenon is often labeled a majorityminority-owner agency problem (La Porta, Lopez-De-Silanes, Shleifer, \& Vishny, 2002).

\section{The Unitary Family in Research on Family Business Governance}

Studies on agency-based governance in family firms, and particularly the foundational studies cited above, share a common assumption that has shaped much of our understanding of family firms: the controlling family acts as a monolithic, unitary actor. This view likely realistically depicts the early evolutionary stages of a family firm, particularly the founder stage, and the prototypical case of naturally aligned sibling partnerships wherein family members benefit from mutual benevolence and blind trust that diminish the need for expensive governance mechanisms (Cruz, Gómez-Mejía, \& Becerra, 2010).

But with the progressive growth of the family tree-owing to the birth of children and grandchildren and the addition of in-laws - family members tend to develop looser ties among each other on average, pursue diverging career paths and interests, and vary in their involvement 
with and goals for the firm. Although family owners may be aligned in their overall desire to increase the economic value of their stakes, they may nevertheless exhibit heterogeneous preferences in terms of their risk appetite, asset classes, liquidity, dividends, time horizon, noneconomic goals, and socioemotional wealth (Chrisman, Chua, Pearson, \& Barnett, 2012; Dunn, 1980; Gomez-Mejia et al., 2011; Kellermanns \& Eddleston, 2004). Indeed, Bertrand and colleagues (2008) suggest that the families who own businesses are not monolithic entities but are composed of individual members who have their own personal objectives and claims. Similarly, Schulze and colleagues (2003) acknowledge that conflicts of interest arise within a family, which may induce family members to question the extent to which they can rely on a single family owner to make decisions that are in the interest of all family members. Most strikingly, the popular press is replete with stories about business families whose members are in severe conflict about the preferred strategic path of the firm and, most often, the allocation and fair distribution of family wealth. Moreover, while family ties may foster a subordination of personal interests to the interests of the family group, they may also spur deviant and opportunistic behavior on the part of family members, which leads to disruptive effects within the family group (Kidwell, Kellermanns, \& Eddleston, 2012).

\section{Family Blockholder Conflicts and Related Agency Costs}

The presence of multiple family owners with diverging goals provides the basis for what we label family blockholder conflicts. The related agency conflicts are distinct from those related to a traditional majority-minority-owner agency conflict, in which (family) blockholders are treated as monolithic actors who expropriate firm wealth to the detriment of (nonfamily) minority owners (La Porta, Lopez-de-Silanes, Shleifer, \& Vishny, 1998; La Porta et al., 2000). In contrast, family blockholder conflicts represent misaligned interests within a blockholder group —in our case the family blockholder group (Bertrand et al., 2008). 
Such agency conflicts are costly, as they can unfold in a particularly destructive manner for the involved blockholders, the corresponding asset base (e.g., the firm, additional family assets), and ultimately all shareholders. In a majority-minority-owner agency conflict, individual minority owners face a collective action problem, as the minority owners bear all the costs from their (e.g., monitoring) efforts but have to share the eventual benefits with all other shareholders (Black, 1992). In contrast, because the conflicting family owners tend to control a substantial number of shares of the firm and to have a substantial amount of personal wealth invested in the firm, they have the power and incentive to influence key strategic decisions (e.g., adjustments to the corporate portfolio, leverage, dividends) in order to enforce their individual preferences. Family owners may thus use their power against other family owners to control access to the firm's money, unseat politically undesirable directors and board members, adapt bylaws in their favor, and, broadly speaking, direct change toward their individual interests (Dodd \& Warner, 1983). Because of the high stakes, the family owners thus have an incentive to escalate family blockholder conflicts, rendering such conflicts particularly expensive to solve.

Family blockholder conflicts lead to the extraction of private benefits of control by the incumbent owner(s), which harms both the other family owners and the minority owners of the firm. Aligning the interests of board and top management team members with those of the owner(s) in power via compensation and incentive schemes is always difficult and costly. Clashes between family blockholders further increase the difficulties and costs by creating loyalty conflicts among directors over which owner's view to follow, as well as an atmosphere of mistrust and uncertainty about the future of the firm. This might engender strategic inertia that ultimately hampers the firm's competitiveness.

Principal-principal conflicts within the family blockholder group can be particularly costly for the family itself. For instance, such conflicts undermine the benefits tied to the joint exercise 
of power as a unified blockholder group, including the uncontested extraction of private benefits of control by the family, the oversight of self-serving managers, and the noneconomic benefits derived from exercising control and imbuing the firm with the family's own strategic preferences (Carney, 2005; Chrisman et al., 2012). Moreover, such conflicts create centrifugal forces within the family that poison family cohesiveness. In conjunction, if not addressed, these effects may undermine the continued influence of the family group as a powerful economic and social actor and ultimately herald its decline as a collective body (Colli, 2003; Franks, Mayer, Volpin, \& Wagner, 2012). In sum, heterogeneous interests among family owners entail family blockholder conflicts that have largely been overlooked in the extant academic literature on family firm governance.

\section{Solving Family Blockholder Conflicts: Separation of the Family from its Assets and the Emergence of Double-agency Costs}

An often observed way for families to curb family blockholder conflicts is to establish an intermediate organizational entity, such as a family office or a family trust, which separates the family owners from their assets. Such intermediary entities create a buffer between family owners and their assets to avoid the uncoordinated interference of the family in the business and thus to limit the destructive dynamics emanating from family blockholder conflicts. Such organizational solutions, however, give rise to another type of agency costs, namely, doubleagency costs, because professional managers who serve as the intermediaries between principals and the agents who actually manage the family's assets occupy a very powerful position. Carney, Gedajlovic, and Strike (2014) compellingly argue that family owners frequently place assets in the hands of intermediary agents such as trusted advisors or related governance entities (e.g., family offices and trusts) and thereby insert a powerful first-tier agent between owners and the second-tier managers of assets. 
In doing so, owners establish a double-agency relationship (Aghion \& Tirole, 1997; Arthurs, Hoskisson, Busenitz, \& Johnson, 2008; Child \& Rodrigues, 2003; Chrisman, Chua, Steier, Wright, \& McKee, 2012) in which agents monitor other agents in a vertical sequence of separation between ownership and control. Carney and colleagues (2014) illustrate that the expected advantage of double agency is based on the idea of employing an incentivized expert to act in the capacity of a fiduciary for the owners by monitoring the actions of the managers of the family's assets. But the particular problem that arises when owners install such a first-tier agent to monitor second-tier agents is that the first-tier agent starts to act as the principal. Reliance on blind trust, an atmosphere of strict confidentiality, a lack of competence among family owners, and a legal setup such as a trust or foundation which restrict owners' discretion over the disposition of their assets (Hansmann \& Mattei, 1998), create significant opportunities for selfdealing by the fiduciary. For the fiduciary, it often suffices to establish a trusted relationship with a limited number of family owners and to secure delegation of authority to start acting as the principal. The fiduciary may use the conferred authority to pass re-interpreted information upward, to put his/her own actions in a favorable light, and to align his/her interests with those of second-tier agents in order to take advantage of the owners rather than protect their interests (Coffee, 2006).

Admittedly, a first-tier agent acting in a fiduciary capacity may use his/her influence in a nonpartisan way, rise to a state of personal disinterest, and serve as the tertius iungens who acts in pure dedication to the family's well-being (Marcus \& Hall, 1992; Obstfeld, 2005; Strike, 2013). But operating in a barely regulated industry ${ }^{1}$ and securely entrenched in the center of a network of contractual relationships with various types of advisors, fiduciaries have many

\footnotetext{
${ }^{1}$ For example, in the U.S., under the Dodd-Frank Wall Street Reform and Consumer Protection Act, family offices are exempt from various reporting and regulatory obligations that apply to banks and other asset managers (the socalled "Private Adviser Exemption" of the U.S. Investment Advisers Act of 1940).
} 
opportunities to acquiesce to these advisors, to pocket kickbacks for services he/she contracts, or to impose preferences that run counter to the owners' interests. Mitigating these double-agency conflicts is especially costly, as owners must align the interests of multiple layers of managers, each of whom have numerous, idiosyncratic opportunities to be in misalignment with owners' interests.

Overall, we depict the management of family firms and, more broadly speaking, family wealth as a finely woven web of agency conflicts. These agency conflicts come in the form of not only principal-agent (Jensen \& Meckling, 1976), altruism-induced principal-agent (Schulze et al., 2001), and majority-minority-owner agency (La Porta et al., 2002) conflicts, which have been discussed in detail elsewhere, but also family blockholder agency conflicts that result from heterogeneous family owner interests. Further, to curb family blockholder conflicts, families often run into double-agency conflicts arising from entrusting a fiduciary as an intermediary between family owners and their wealth. Table 1 summarizes the multiple types of agency conflicts in family firm governance.

Insert Table 1 and Figure 1 about here

In response to the various types and levels of blockholder conflicts that might occur, we expect that families will vary in the degree to which they separate themselves from their assets, i.e., their level of delegation of power to an intermediary governance structure. In the following, we will explore four types of family governance structures often observed in practice through which families increasingly separate the family from its assets: (1) uncoordinated family, (2) embedded family office, (3) single family office, and (4) family trust. We thereby suggest that the progressive separation of family and assets reduces family blockholder costs but simultaneously increases double-agency costs. Figure 1 depicts the four structures and illustrates how they vary 
in the separation of family and wealth and how they differ in their susceptibility to family blockholder and double-agency costs.

\section{FAMILY GOVERNANCE STRUCTURES AND RELATED AGENCY COSTS}

\section{No Separation of Family and Assets: The Uncoordinated Family}

The uncoordinated family pertains to a governance form wherein control over the management of family wealth is kept in the hands of the family, without any coordination of family member interests. Without the coordination of heterogeneous familial interests, each family owner has unmediated and potentially uncontrolled access to the family's assets within legal confines (e.g., marital, heritance, and testamentary law; contracts of inheritance) (Marcus, 1991). As such, there is no separation of family and assets.

This constellation is likely prevalent among families with a powerful patriarch or matriarch or among families with a history of limited family and asset complexity, which has rendered the alignment of family owner interests unnecessary. As such, it is particularly prominent among founding and second generations. Yet families of later generations with more complex ownership structures might also be unable or unwilling to separate the family and its assets, for instance, to minimize the related expenses of setting up and running a wealth management system and to ensure privacy.

The lack of coordination, however, may result in significant agency costs for the family. Most important in light of our theorizing, the absence of coordinating mechanisms represents a fertile ground for family blockholder conflicts to play out. As described by Bertrand et al. (2008), the uncoordinated heterogeneous interests of family owners may provide them with incentives to tunnel resources to themselves before relatives are able to do so. These dynamics can take the form of overt infighting for the family's resources, or more subtly, incentives for thriftless, extravagant, and wasteful lifestyles. A divergence of interests thus induces a race to the bottom 
over the family's assets; it will appear rational for many family members to engage in an unseemly internal struggle for power and money (Morck, Strangeland, \& Yeung, 2000).

Consequently, despite advantages in terms of minimized expenses, increased privacy, and particularly the lack of double-agency costs (due to the absence of an intermediary), the uncoordinated family constellation is highly susceptible to family blockholder conflicts. Moreover, in this constellation, welfare losses for the family emanate from forgone economies of scale and knowledge advantages that would accrue to all owners from deference to professionals and coordinated action, especially in terms of the management of wealth and the joint exercise of monitoring and control as a united group. Taken together, the uncoordinated family therefore constitutes a very fragile governance form and, over the longer run, represents a recipe for the dissolution of family wealth and the decline of the family as the collective owner of wealth (Colli, 2003; Franks et al., 2012; Zeitlin, 1974).

The fragility of the uncoordinated family may be temporarily mitigated by the involvement of a powerful family representative, such as the founder of the family's fortune or a senior patriarch/matriarch who holds uncontested authority over other family members. Alternatively, a will can block family members' transgressions and unrestrained access to the family's wealth. But as soon as these restraints are lifted (e.g., owing to the death of the founder or patriarch/matriarch) (Gilding, 2005), the disruptive forces that fuel the downward-spiraling lemming's race for the family's money will begin. Similarly, poor asset performance will place the uncoordinated family under increased pressure. Family members have incentives to maintain the status quo and to subordinate their individual interests to the interests of the family as long as performance is satisfactory. Declining performance, however, is likely to bring diverging interests to the fore and to create an incentive for individual family members to run for the exit 
with the largest possible fraction of the family's fortune. Table 2 summarizes the key characteristics of uncoordinated families.

\section{Low Level of Separation: The Embedded Family Office}

In the case of an embedded family office, the family installs a hybrid two-tier structure to manage its affairs by appointing a fiduciary from within the existing asset structure. For instance, and as often observed in practice ${ }^{2}$, the family may ask the accountant, treasurer, or chief financial officer of the focal family firm to also manage the family's wealth (Rosplock, 2013). In so doing, the family delegates the management of part of the family affairs to a nonfamily member but does so within the original two-tier structure. In addition to their job in the firm's operations, embedded family officers are, for instance, entrusted with the management of the family's noncorporate assets, such as liquid wealth and real estate, and responsible for fulfilling related services such as personal bookkeeping and tax filings (Flanagan et al., 2011). As such, there is a low level of separation between the family and its assets. This governance structure is particularly attractive to families with a trusted manager embedded within the existing asset structure seeking a convenient and cost-efficient solution to the family's wealth governance challenges. Such a structure may evolve from the progressive success of the focal family firm and the accumulation of wealth on the side of the family over time and generations.

However, embedded family offices aid little in aligning diverging family member interests with regard to the firm and hence in alleviating family blockholder conflicts (Flanagan et al., 2011; Marcus \& Hall, 1992; Rosplock, 2013). The reason for this is that while embedded family offices bundle the individual family members' wealth management activities, they provide little guidance for how to handle the diverging interests of family members. Moreover, embedded

\footnotetext{
${ }^{2}$ Indeed, research suggests that there are about 18,000 embedded family offices in the U.S. (Rosplock, 2013). For Germany, Sieger and Zellweger (2013) find that in a sample of owners of mid-sized companies, the CFO on average manages $60 \%$ of the family's private wealth.
} 
family offices often create an incentive for family owners, and eventually even nonowning family members, to escalate their personal demand for subsidized services, particularly when the embedded family office offers its services to the family for free or below-market costs.

At the same time, however, the embedded family office gives rise to some level of doubleagency costs: the embedded family officer will gain preferred access to owners and their most private financial circumstances and will thus emerge as an influential information and power broker. Such an embedded family officer may be tempted to steer decisions in a direction that mainly serves his/her own interests, that extends his/her sphere of influence, and that undercuts the position of the CEO to whom he/she reports. Such double-agency costs will likely be particularly pronounced if large fractions of the total family wealth are managed through the embedded family office.

Regarding further agency costs, it is also important to consider that an embedded fiduciary serves two masters, the family and the firm, which sometimes have diverging interests (Hiebl, 2014). The ensuing dilemma about which master to serve comes in many forms, such as a risky private investment for which a family member seeks financial backing from the firm, family members' preference for tax structures that protect their private interests to the detriment of the firm, or pressure to pay dividends when the firm needs additional equity injections. Given the family's influence, it can be difficult for the embedded fiduciary to oppose the family's wishes. Such governance inefficiencies are costly for a firm's minority owners, creditors, and other family owners. Additionally, because the embedded fiduciary takes orders directly from both the CEO and family owners, the CEO is placed in the difficult position of having a subordinate who is simultaneously the trusted advisor of the party to whom the CEO reports. Such a hybrid hierarchical structure stands in sharp contrast to unambiguous and efficient control structures. The CEO thus lives with a costly substructure that does not actually serve the company and 
operates outside his/her immediate control, but under the direct protection of the family owners. As a consequence, resources may be allocated according to family-political criteria instead of firm-level efficiency-based criteria, which highlight further important inefficiencies for a firm's minority owners, creditors, and any family owners who do not have access to the services of the internal advisor.

Additional costs of the embedded family office constellation arise not only from the opportunistic behavior of the embedded fiduciary but also his/her potential incompetence in fulfilling certain tasks (such as asset-management decisions regarding the family's wealth) for which the fiduciary is often untrained. In sum (see also Table 2), embedded family offices solve family blockholder conflicts to only a limited degree but give rise to some level of double-agency costs. Embedded family offices engender majority-minority-owner/creditor agency costs from the fulfillment of various services for the family and from governance inefficiencies due to the hybrid hierarchical position of the embedded fiduciary.

\section{High Level of Separation: The Single Family Office}

Over time, families may further increase the level of separation between the family and its assets and install a single family office, a separate legal entity placed between the family and its assets that is solely devoted to the management of the affairs of a single family (Amit, Liechtenstein, Prats, Millay, \& Pendleton, 2008; Gray, 2005; Rosplock, 2013; Welsh, Memili, Rosplock, Roure, \& Segurado, 2013; Wessel, Decker, Lange, \& Hack, forthcoming). While precise numbers for the prevalence of family firms are lacking, estimates range from 5,000 to 10,000 single family offices in the U.S. alone (Rosplock, 2013). Motivations for setting up a single family office include the family's desire to professionalize the management of its affairs, fear that next generation members lack the competency to manage the family's wealth, or wish to restrict individual family members' access to the family's wealth (Welsh et al., 2013). Because a family office limits 
children's access to the family fortune, it may help in preserving their initiative, self-esteem, and social relationships (Gilding, 2005). Additionally, the pooling of family assets provides economies of scale in asset management and may serve to minimize the family's tax obligations under certain regulations (Marcus, 1991).

Most important, a single family office serves as a unifying force that reduces family blockholder conflicts: it thwarts the centrifugal forces inside the family owing to generational drift and the related dilution of wealth so that the family maintains cohesion and power over time and preserves its wealth (Gilding, 2005). Thus, single family offices directly address family blockholder conflicts owing to the formalization of investment guidelines and the delegation of all wealth management tasks to one professional fiduciary.

However, these advantages come at significant costs. Depending on the family officer's level of alignment with the interests of the family, single family offices are susceptible to doubleagency costs. Such costs could be severe in single family offices run by nonfamily professionals because both the first-tier agent (the family officer) and the second-tier agents (the managers of the various assets) work in different organizations and thus are outside the reach of hierarchical intra-organizational control ${ }^{3}$. The principal's limited insight into the family officer's dealings with the asset managers creates significant opportunities for self-dealing. For instance, service providers and asset managers will venerate the family officer and propose various inducements to sell their services and to ultimately obtain access to the family's wealth. Capitalizing on the principal's limited insight and possessing a significant information advantage, second-tier agents will try to become complicit with the first-tier agent and acquiesce in his/her decisions to pursue their own collusive interests (Carney et al., 2014).

\footnotetext{
${ }^{3}$ The agency costs in the relationship between the principal and the first-tier agent (i.e., the family officer) are easier to keep in check because of the strong incentive among principals to monitor the cost efficiency of the family office and to hold the family officer accountable. Single family offices should thus be less prone to traditional ownermanager agency conflicts.
} 
In addition to double-agency costs, single family offices generate direct costs from running outside the current asset structure. Although single family offices tend to be small ${ }^{4}$, the personnel costs for professionals, as well as the costs for office and technology infrastructure, are often significant in relation to the wealth to be managed. In contrast to the embedded family office, in the single family office, the family itself pays the bills rather than the firm, where the costs are at least partly passed along to minority owners and creditors. The overall efficiency of the family office will thus be a significant concern inside the family, creating an incentive for the family to carefully monitor the cost-conscious behavior of family officers ${ }^{5}$.

The double-agency costs should be largely contingent on the proportionate distribution of power and therefore on the degree to which the family is able to monitor the family officer's dealings with second-tier agents ${ }^{6}$. For instance, double-agency costs should be more pronounced if the family officer faces little consequences if caught in collusive dealings, such as when there are attractive job alternatives outside the family office, both in economic terms and in access to a certain social class (Weber, 1978). Double-agency costs should also be more pronounced if the family possesses no monitoring mechanisms that tie the total costs from running the family office, including fees to second-tier agents, to the total assets under management. Similarly, double-agency costs should be particularly prominent in the absence of incentive systems tied to the preservation and growth of the family's wealth (Rosplock, 2013; Varian, 1990). Conversely, double-agency costs are a lesser concern in the presence of a most trusted advisor (Strike, 2013) who rises to a state of pure rationality, disinterest, and stewardship (Marcus \& Hall, 1992). In

\footnotetext{
${ }_{5}^{4}$ In the U.S., the average number of employees in a single family office is 8.7; see Amit et al. (2008).

${ }^{5}$ These dynamics explain why many single family offices transform into multi-family offices and hence develop some commercial activity over time (Rosplock, 2013). Starting as discrete and private organizations with a strong cost focus, single family offices progressively transform into business-centric organizations that offer their services to multiple clients.

${ }^{6}$ Double-agency costs should be limited if a family member serves as the family officer, as the family member has a particular incentive to closely monitor second-tier agents given the trust built into familial relationships (Wessel, Decker, Lange, \& Hack, forthcoming). However, the appointment of a family member as a family officer should raise altruism-induced agency costs.
} 
such cases, as chronicled by Dunn (1980), family offices can play an important role in reallocating capital from low- to high-value activities. Moreover, double-agency costs should be mitigated if the family holds ownership in its most valuable assets not only through the family office but also directly through individual family members. Similarly, the family may occupy a seat in the firms' supervisory or even management boards. Direct ownership of and involvement in the governance of critical assets secure for the family unmediated access to relevant information about the activities of second-tier agents, which deters misbehavior by the first-tier agent.

\section{Complete Separation: The Family Trust}

To solve their governance complexities, families may also install a solution with complete separation between the family and its assets. Typically, this combination is reflected in the form of a trust in common law countries, such as the U.S., the U.K., and Scotland, as well as Japan, Israel, and some Latin American countries (Hansmann \& Mattei, 1998). Civil law countries, and therefore most continental European countries, make provisions for trust-like relationships such as foundations. What is common to both forms is that a transferor (in the trust, the settlor) allocates wealth to a trust or a foundation for the benefit of a recipient (the beneficiary). To this end, the transferor installs a manager (the trustee) who promises to manage the wealth for the benefit of the recipient and in accordance with the ex-ante instructions of the transferor (Langbein, 1997; Sitkoff, 2004) ${ }^{7}$. While few reliable statistics on the number of family trusts are available, in the mid-1990s Langbein (1997) estimated that in the U.S. more than 650 bn USD are held in personal trusts such as family trusts. For the U.K., the UK Trust Statistics ${ }^{8}$ reports a

\footnotetext{
${ }^{7}$ In the case of a foundation, the transferor formally transfers the property to the manager of the foundation, whereby the foundation becomes its own owner. A trust, in contrast, can be considered a nexus of contracts between three parties (settlor, beneficiary, and trustee). Trust law is thus distinct from commercial, property, and contractual law. For the related legal debate, refer to Sitkoff (2004).

${ }^{8}$ See: http://www.gov.uk/government/collections/trusts-statistics--2
} 
total number of 160,500 family trusts in 2014 , however does not provide numbers on the total assets held by these institutions.

In all international variations of trust law, the beneficiary forgoes all property rights in the wealth placed inside the trust and has very limited abilities to monitor the trustee (Boxx, 2012; Hansmann \& Mattei, 1998). The beneficiary is thus deprived of ownership rights, which are instead placed in the hands of the trustee. In agency terms, beneficiaries rely heavily upon powerful, entrenched trustees. Deferring to trustees reduces the visibility of the details of the trust, increases the dependence of the beneficiary on the trustee, and facilitates the trustee's rise to the role of a powerful gatekeeper (Coffee, 2006). In fact, no trustee, whether in or out of office, has personal liability vis-à-vis the trust's outside creditors. But the beneficiaries are residual claimants over trust assets, and thus, they bear the full risk (Sitkoff, 2004).

In the family firm context, and particularly in the U.S., family trusts are common vehicles for structuring family wealth. In fact, family trusts have several attractive features (Boxx, 2012): for instance, trusts spare the family from federal estate and generation-skipping taxes (Dukeminier \& Krier, 2003). To a large degree, trusts also allow settlors to preserve the status quo, entomb their lifetime achievements, create a personal legacy, and thus satisfy some sort of longing for immortality (Friedman, 1964) ${ }^{9}$. Additionally, trusts are an attractive means for parents (often the settlors) to limit children's (the beneficiaries) access to wealth to quell fears that the children will ruin the assets (e.g., the family firm) or, conversely, that the wealth will ruin the children by enticing them to pursue extravagant lifestyles and by undermining their

\footnotetext{
${ }^{9}$ In U.S. trust law, the "dead hand" of the settlor must, however, vest within 21 years after the expiration of some "life in being" when the interest was created (Dukeminier \& Krier, 2003; Schanzenbach \& Sitkoff, 2006). The background of this rule is that the settlor is assumed to realistically assess the capabilities of living members of his/her family. But the settlor cannot know anything about unborn persons. Hence, the settlor is permitted to control only so long as his/her judgment is informed with an understanding of the capabilities and needs of persons alive when the judgment was made. U.S. judges over time fixed this period as lives in being plus 21 years thereafter (Dukeminier \& Krier, 2003). Limiting dead-hand control is also important from an economic efficiency standpoint, as it keeps property marketable and avoids the entombment of wealth subjected to inefficient use.
} 
initiatives. Because of the formalization and the severely limited access of family members to the wealth, trusts are envisaged as powerful tools to avoid the emergence of family blockholder conflicts.

However, trusts can engender substantial double-agency costs. Despite strict legal standards and trustees' significant liability exposure from ex-post sanctioning of self-dealing (e.g., Cooter \& Freedman, 1991; Easterbrook \& Fishel, 1993; Langbein, 2005), in many cases, the law is an insufficient substitute for monitoring. In her commentary on trust law for family firms, Boxx (2012, p. 239) notes: “The beneficiary has virtually no control over the trustee's actions, restricted ability to monitor the trustee's actions, and restricted ability to exit the relationship by removing the assets from the trustee's control. There is also no other monitoring mechanism in place to protect the beneficiary, such as court supervision in a guardianship or market forces affecting the price of stock in a publicly held corporation." In other words, important internal and external governance mechanisms to monitor and sanction managers that are available in the corporate world are unavailable for trusts (Peng \& Jiang, 2010). Because the trustee has unfettered discretion over investments and because the likelihood of getting caught is low (Boxx, 2012; Sitkoff, 2004), there is little to stop the trustee agent from exploiting his/her position. Furthermore, when a task is delegated to a manager with wide discretion but without close monitoring, it is even more difficult to ensure alignment of second-tier agents' interests with the interest of the beneficiary. It may then become tempting to allocate generous fees by second-tier agents to the trust corpus and to engage in collusive dealings between trustees and asset managers ${ }^{10}$. Put differently, because the first-tier agent already has significant opportunities

\footnotetext{
${ }^{10}$ Interestingly, the code of professional conduct of the Society of Trust and Estate Practitioners (STEP) acknowledges this threat of collusion from double agency and stipulates that "a member of the society must fully disclose any fee, commission, rebate, compensation, or benefit to be received from a person or entity other than the client at the outset of rendering any service or providing advice.” Refer to STEP (2009, p. 6), www.step.org.
} 
for self-dealing, second-tier agents are even less likely to align their interests with those of the beneficiary and even more likely collude with the trustee to the detriment of the beneficiary ${ }^{11}$.

In addition to double-agency costs, trusts are also likely create significant principal-agent agency costs, namely, settlor-trustee and beneficiary-trustee agency costs. The former arise from the lack of loyalty of the trustee to the ex-ante instructions by the settlor who established the trust. For instance, the trustee may use his/her discretion to partly reinterpret the settlor's instructions to favor him- or herself or a third party of his/her choice. The latter arise from the lack of loyalty of the trustee to the beneficiary and the opportunities for self-dealing described above. These two subtypes of principal-agent agency costs are impossible to solve in the classic way through monitoring and incentive contracting. Indeed, managerial ownership as a particularly effective incentive mechanism is unavailable for trusts. Additionally, there is no efficient market for stakes in private trusts, which would provide price signals and thus meter trustee performance (Schanzenbach \& Sitkoff, 2006; Sitkoff, 2004). To some degree at least, the trustee thus becomes a manager without an owner. Trustees may then be tempted to exploit their position, and because of the fear of the harsh legal sanctions in the unlikely scenario that they are caught, they are likely to develop significant creativity in concealing their eventual self-dealing.

Finally, appointing a trustee or multiple trustees to manage family wealth also leads to direct costs from the bureaucratization of wealth in trust form. To administer a diversified portfolio of assets, trustees need asset-management expertise; thus, they must hire professionals who will require compensation for their services ${ }^{12}$.

\footnotetext{
${ }^{11}$ Similar to our discussion on the single family office, appointing a family member as a trustee could decrease double-agency costs, but at the same time could increase altruism-induced agency costs.

${ }^{12}$ These costs are likely lower for a trust than for a family office where all costs accrue to a single family. Professional trustees work for multiple clients; hence, they can offer their services at lower costs compared with a single family office. The profession of trust and estate practitioners has progressively surfaced over the last few decades, with its own professional qualifications, industry standards, code of conduct, and industry associations. For instance, the Society of Trust and Estate Practitioners (STEP) was founded in 1991.
} 
The agency costs tied to trusts are likely contingent on several boundary conditions. For instance, we expect double-agency and principal-agent costs to arise once the settlor who established the trust is no longer capable of overseeing the workings of the trust. When setting up a trust, the settlor has an interest in appointing trustees whom he/she trusts. However, trustee loyalty will decrease and both double-agency costs and settlor/beneficiary-trustee agency costs will increase once the settlor is unable to oversee the dealings inside the trust, for instance, because of illness or death. In contrast to the uncoordinated family, where the departure of a patriarch/matriarch results in a race to the bottom for the family's wealth, in the case of a trust, the beneficiaries' access to wealth remains restrained. However, the trustee's position becomes even more powerful, as he/she now is enthroned as the undisputed custodian of the wealth and related affairs, free from monitoring by the settlor by whom he/she was originally appointed. The trust then largely takes on a life of its own.

Similarly, we expect double-agency costs and principal-agent costs to be particularly pronounced if the legal and organizational setup of the wealth administered through the trust is opaque. Indeed, in a descriptive study of the hundred wealthiest families in Germany, Zellweger and Kammerlander (2014) find that the wealth of these families is mostly concentrated in one to three dominant equity stakes. However, the total wealth of these families is held by 75 legal entities on average, such as intermediary holdings and investment vehicles, as well as foundations and trusts. These entities are often connected in a nontransparent web of horizontal and vertical cross-holdings, which create a separation of family and wealth to a particular degree; thus, they create strong opportunities for self-dealing across the multi-tier structure. Settlors may themselves stand at the beginning of such impervious structures, given that the complexity of an asset's formal organization increases the difficulty of undermining it from within, which is one source of its strength against fragmentation (Marcus, 1991). Over time, beneficiaries will likely 
lose an overarching view of the assets because of the complexity. Thus, we expect that trusts in combination with opaque asset structures are likely to create particularly high double-agency and principal-agent costs.

\section{Distributive Effects over Time}

These overall reflections on the four governance forms with various levels of separation between family owners and their assets are depicted in Table 2. Our analysis also allows us to draw inferences about the stability of the governance forms and ultimately the distributive effect for family wealth over time. In the case of the uncoordinated family, family wealth is likely to be rather rapidly dissolved and distributed to individual family members, given the existence of rampant family blockholder conflicts. In embedded family offices, family wealth is kept intact, but it is at risk of being managed according to family-political instead of efficiency-based criteria. Single family offices should also be able to preserve family wealth but at significant governance and administrative costs. Finally, trusts entomb family wealth and create significant agency costs, which should gradually deplete family wealth over time.

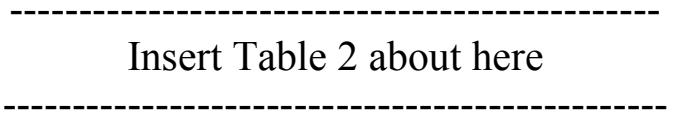

\section{DISCUSSION AND CONCLUSION}

With the present study, we attempt to make three contributions to the literature. First, departing from a unitary-family perspective, we shift the governance discussion in family firms to a constellation with multiple family owners having diverging preferences. This shift in the level of analysis is of particular relevance for larger families who often oversee significant wealth, namely, "old money families." While somewhat limited in their number, these families nonetheless oversee substantial amounts of capital (Economist, 2014; Piketty, 2014; Rosplock, 2013). Moreover, wealth governance should become an important topic for consideration for all 
family firms in the transition from a lone founder firm or sibling partnership to a cousin consortium in order to avoid a detrimental race to the bottom, as is common among uncoordinated family firms. Second, we discuss two understudied types of agency costs, which might be relevant for family firm research in general as well as agency-based research on governance (e.g., Lan \& Heracleous, 2010): family blockholder agency costs, which arise from heterogeneous family owner interests, and double-agency costs, which arise from the separation of family owners and their assets as an attempt to curb family blockholder conflicts. Doubleagency costs thus result from the placement of an intermediary professional or organizational entity between the family principals and the managers of a family's wealth (e.g., the corporate managers). Given the high number of embedded and single family offices (Rosplock, 2013) and trusts around the world, studying these agency costs is crucial to fully understand family businesses and business families. Third, we discuss four governance forms (uncontrolled family, embedded family office, single family office, and family trust), which differ in the level of separation between the family and its assets. We elaborate on the motives for their establishment, their benefits, and the related (agency) costs. In particular, we explore how the progressive separation of family and wealth in the pursuit of reduced family blockholder costs fosters the emergence of double-agency costs.

In this paper, we thus directly answer Carney et al.'s (2014) call for more rigorous analysis of the agency costs and benefits of family (firm) governance. In particular, we systematically study how double-agency costs can emerge from families' attempts to mitigate family blockholder conflicts by separating the family from its assets. Moreover, we advance this stream of literature by highlighting contingencies that either reinforce or alleviate double-agency costs. We also provide a fresh approach to recent academic discussions on the role of family offices, trusted advisors, and family wealth governance (Davis, Craig, Dibrell, \& Green, 2013; Reay, 
Pearson, \& Dyer, 2013; Salvato \& Corbetta, 2013; Strike, 2013). Answering recent calls for more profound and stringent theory building on the role, attributes, and effectiveness of trusted advisors (Strike, 2012), we develop an integral theoretical framework based on agency.

While the desire to align the diverging interests of family owners is one important root cause of the separation of family and assets, governance constellations such as family offices and trusts can also be set up to address a related yet distinct challenge of "old money families": the management of multiple assets. Such multiple asset constellations are very common around the world, mainly among later-generation wealthy families. For instance, among U.S. families in business, Zellweger, Nason, and Nordqvist (2012) show that only $10 \%$ of the families in their sample control a single firm and that on average these families control more than three firms. Similar evidence for an extended portfolio of business activities can be found in studies exploring family firms in Europe and Latin America (Michael-Tsabari, Labaki, \& Kay Zachari, 2014; Sieger, Zellweger, Nason, \& Clinton, 2011). Although these studies provide striking evidence for family control beyond a single firm, they most likely still underestimate the scope and complexity of many family's wealth, as they fail to capture other than corporate assets and assets held through trusts, nominee accounts, and shell holding companies (Carney \& Child, 2013). However, liquid wealth and real estate are integral and often substantial parts of the total family wealth and are thus subject to heterogeneous family member interests and, ultimately, family blockholder conflicts (Dunn, 1980; Gray, 2005). Overseeing and managing a complex base of multiple assets (instead of a single firm) is likely beyond the capabilities of the family members; thus, this task is delegated to a professional—for instance, a family officer or trustee.

Managing a complex asset base does not necessarily require the installation of one of the governance mechanisms introduced above. Instead, families might opt to manage their firms in parent-subsidiary structures in business groups (e.g., Almeida \& Wolfenzon, 2006; Carney et al., 
2011; Gedajlovic et al., 2012). The family business group literature presents various examples of families controlling multiple firms (Carney \& Child, 2013; Luo \& Chung, 2005; Morck \& Yeung, 2003). Such business groups are surprisingly prominent even under strong institutional regimes, such as in Sweden, where the Wallenberg family controls approximately $40 \%$ of the Swedish stock market capitalization, with stakes in approximately 20 firms (Collin, 1998). While the family business group literature has studied majority-minority-owner agency costs in family firms (Morck \& Yeung, 2003), we highlight the importance of further agency conflicts. Without alignment of family members' interests, family blockholder conflicts might further detract from the overall success of such groups (Carney et al., 2011). Moreover, double-agency costs similar to those described in this manuscript might occur if professional managers are hired to oversee the performance of subsidiary firms. We also extend the family business group literature (Almeida \& Wolfenzon, 2006; Carney \& Child, 2013; Gedajlovic et al., 2012; Luo \& Chung, 2005 ) in that we show (1) how multiple types of (not only corporate) assets are controlled by a family, and (2) how the governance of such wealth structures works out in practice, with the resulting advantages and disadvantages in terms of related (agency) costs.

While much of the research that deals with entrepreneurship in family businesses has focused on the creation of wealth by families (e.g., Habbershon \& Pistrui, 2002; Hoy \& Sharma, 2009; Nordqvist \& Melin, 2010), we explore the preservation and, in part, the break-up and decline of family wealth (Chandler, 1977; Franks et al., 2012). Carney et al. (2014) mainly explore institutional reasons for variance in the longevity of family firms, whereas we take a micro perspective and explore the longevity of family firms through a governance- and agencybased perspective. By investigating various agency costs, we offer empirically testable predictions for these trends. Our study thus provides insights for economic sociology and anthropology through the exploration of the agency forces that can secure or undermine the 
persistence of family wealth and what has been labeled "family spheres of influence" (Marcus, 1991; Zeitlin, 1974) in western economies.

\section{Limitations and Future Research}

We should also note some important limitations of our study. Constellations other than the four governance types presented above exist in practice, such as those involving various types of advisors, asset managers, and multifamily offices, which service multiple families (Lang \& Stulz, 1994; Wessel et al., forthcoming). However, our limited knowledge of family and wealth governance at this stage justifies an in-depth discussion of prototypical governance constellations, based on which further refinements should be possible. Moreover, our paper treats the four governance constellations as mutually exclusive choices. In the future, it will be interesting to explore various combinations of these structures. Whereas flexibility and limited coordination may be useful for certain assets to satisfy the individual aspirations of family members, equity investments in a legacy family firm may be best managed through a closely monitored family office, and philanthropic activity may be best allocated to a trust. Such combinations may minimize agency costs depending on asset types and strategic goals.

Furthermore, our study makes rather sweeping assumptions about the role of law and the institutional context in shaping agency costs (Foley \& Greenwood, 2010; Franks et al., 2012). For instance, and as illustrated by Marcus (1991), Beckert (2007), and Carney and colleagues (2014), legal arrangements in the form of fiduciary and inheritance law, and specifically testamentary freedom therein (Ellul, Pagano, \& Panunzi, 2010), are more or less permissive with respect to the entombment of capital. Moreover, the personal liability of trustees varies across countries. Therefore, the role of legal and tax systems in shaping legal surrogates such as family offices and trusts deserves further investigation, particularly in light of the growing popularity of such surrogates (Carney et al., 2014). Future research could also explore the inner workings of the 
different governance constellations in more detail and could thereby test our predictions. Additionally, researchers could illuminate the dynamics within the governance forms, particularly within the uncoordinated family. Drawing on game theory may be helpful in this regard. Most important, researchers should explore the role of shareholder agreements and family constitutions, since families may also opt for non-organizational solutions to mitigate family blockholder conflicts.

Families sometimes attempt to avoid such conflicts by reverting to a contractual solution. Shareholder agreements, for instance, regulate the execution of voting rights or the transfer of shares within and outside the family pool (see Chemla, Habib, \& Ljungqvist, 2007 for details). However, they are ill-suited to address questions that are mainly of a managerial nature, such as a firm's strategic position, growth aspirations, risk taking, dividend policy, remuneration schemes, and family member employment, but that have potentially important consequences for family shareholders. Moreover, they are unable to solve issues associated with overseeing complex asset bases with multiple legal entities, and/or in presence of multiple asset classes. It is not surprising that families then revert to further governance instruments, such as family constitutions, which aim to address some of these additional sources of misalignment and conflict, even though such regulations have only a symbolic character and are not legally binding (Aronoff \& Ward, 1996).

It holds further promise to study the overall economic effects of the four governance constellations. Given the inherent agency costs and trend toward risk aversion, researchers could explore whether trusts, instead of asset (re-)allocation in new entrepreneurial ventures, entomb wealth and create "zombie" institutions at significant economic opportunity costs. Such costs may arise because inherently risky investments are at odds with the trustee's duty of prudence, which directs the trustee to avoid risks, diversify wealth, and hence move out of risky entrepreneurial assets (Boxx, 2012; Hawley \& Williams, 2000; Langbein \& Posner, 1976). 
Morck, Strangeland, and Yeung (2000) allude to this possibility when finding that countries grow more slowly when the share of old money wealth in proportion to GDP is large, and they hypothesize that governance structures of old money families entrench poor management and slow creative destruction. In this regard, the overall skepticism in many western populations about the value of holding inherited wealth is an area ripe for future research (Piketty, 2014) ${ }^{13}$. Finally, our discussion of double-agency costs may serve as a useful conceptual lens to illuminate the efficiency of fiduciaries and "gatekeepers" (Coffee, 2006), particularly the workings of pension funds, rating agencies, and sovereign wealth funds (Hawley \& Williams, 2000).

To conclude, with the present paper, we have aimed to start a new dialogue about governance in business-owning families. Exploration of this topic not only provides wide practical insights but also enriches our theories about the rise and decline of family wealth over time. We hope that our considerations fuel further research toward filling some of these important research lacunas.

\footnotetext{
${ }^{13}$ On the overall image of hereditary wealth in the U.S., Marcus (1991, p. 108) writes: The "overall and long-term cultural reaction to business fortunes passed to descendants has been negative. Unlike England, the U.S. has had no embedded aristocratic or explicit class tradition in which old business wealth could find a cultural refuge. When in the public view, later generations of family/business formations have sought an uneasy justification in philanthropy and public service careers. Yet, their preference has been for inattention and privacy in a culture which thrives on the recognition of celebrities."
} 


\section{REFERENCES}

Aghion, P., \& Tirole, J. (1997). Formal and real authority in organizations. Journal of Political Economy, 105(1), 1-29.

Almeida, H. V., \& Wolfenzon, D. (2006). A theory of pyramidal ownership and family business groups. Journal of Finance, 61(6), 2637-2680.

Amit, R., Liechtenstein, H., Prats, M. J., Millay, T., \& Pendleton, L. P. (2008). Single family offices: Private wealth management in the family context, Research Report. Philadelphia: Wharton School.

Anderson, R. C., \& Reeb, D. M. (2003). Founding-family ownership and firm performance: Evidence form the S\&P 500. Journal of Finance, 58(3), 1301-1328.

Aronoff, C. E., \& Ward, J. L. (1996). Family business governance: Maximizing family and business potential, Marietta, GA: Family Enterprise Publisher.

Arthurs, J. D., Hoskisson, R. E., Busenitz, L. W., \& Johnson, R. A. (2008). Managerial agents watching other agents: Multiple agency conflicts regarding underpricing in IPO firms. Academy of Management Journal, 51(2), 277-294.

Beckert, J. (2007). Inherited Wealth. Princeton, N.J.: Princeton University Press.

Bertrand, M., Johnson, S., Samphantharak, K., \& Schoar, A. (2008). Mixing family with business: A study of Thai business groups and the families behnd them. Journal of Financial Economics, 88, 466-498.

Black, B. (1992). Agents watching agents: The promise of institutional investor voice. UCLA Law Review, 39, 811-893.

Boxx, K. E. (2012). Too many tiaras: Conflicting fiduciary duties in the family-owned business context. Houston Law Review, 49(2), 233-290.

Carney, M. (2005). Corporate governance and competitive advantage in family-controlled firms. Entrepreneurship Theory and Practice, 29(3), 249-265.

Carney, M., Gedajlovic, E., \& Strike, V. M. (2014). Dead money: Inheritance law and the longevity of family firms. Entrepreneurship Theory and Practice, 6, 1261-1283.

Carney, M., Gedajlovic, E. R., Heugens, P. P., Van Essen, M., \& Van Oosterhout, J. H. (2011). Business group affiliation, performance, context, and strategy: A meta-analysis. Academy of Management Journal, 54(3), 437-460.

Carney, R. W., \& Child, T. B. (2013). Changes to the ownership and control of East Asian corporations between 1996 and 2008: The primacy of politics. Journal of Financial Economics, 107, 494-513.

Chandler, A. (1977). The visible hand: The managerial revolution in American business. Cambridge, MA, US: Belknap Press/Harvard University Press.

Chemla, G., Habib, M. A., \& Ljungqvist, A. (2007). An analysis of shareholder agreements. Journal of the European Economic Association, 5(1), 93-121.

Child, J., \& Rodrigues, S. B. (2003). Corporate governance and new organizational forms: Issues of double and multiple agency. Journal of Management and Governance, 7, 337-360.

Chrisman, J., Chua, J., Steier, L., Wright, M., \& McKee, D. L. (2012). An agency theoretic analysis of value creation through management buy-outs of family firms. Journal of Family Business Strategy, 3(4), 197-206.

Chrisman, J., Chua, J. H., Pearson, A. W., \& Barnett, T. (2012). Family involvement, family influence, and family-centered non-economic goals in small firms. Entrepreneurship Theory and Practice, 36(2), 267-293.

Chrisman, J. J., Chua, J. H., \& Litz, R. A. (2003). A unified systems perspective of family firm performance: An extension and integration. Journal of Business Venturing, 18(4), 467-472.

Chrisman, J. J., Chua, J. H., \& Litz, R. A. (2004). Comparing the agency costs of family and non-family firms: Conceptual issues and exploratory evidence. Entrepreneurship Theory and Practice, 28(4), 335-354. 
Claessens, S., Djankov, S., Fan, J. P. H., \& Lang, L. H. P. (2002). Disentangling the incentive and entrenchment effects of large shareholdings. Journal of Finance, 57(6), 2741-2771.

Coffee, J. C. (2006). Gatekeepers - The professions and corporate governance. Oxford: Oxford University Press.

Colli, A. (2003). The history of family business, 1850 - 2000. Cambridge: Cambridge University Press.

Collin, S. O. (1998). Why are these islands of conscious power found in the ocean of ownership? Institutional and governance hypotheses explaining the existence of business groups in Sweden. Journal of Management Studies, 35(6), 719-746.

Cooter, R., \& Freedman, B. J. (1991). The fiduciary relationship: its economc character and legal consequences. N.Y.U. Law Review, 66, 1045-1075.

Cruz, C. C., Gómez-Mejía, L. R., \& Becerra, M. (2010). Perceptions of benevolence and the design of agency contracts: CEO-TMT relationships in family firms. Academy of Management Journal, 53(1), 69-89.

Davis, W. D., Craig, J., Dibrell, C., \& Green, J. (2013). The effects of goal orientation and client feedback on the adaptive behaviors of family enterprise advisors. Family Business Review, 26(3), 215-234.

Demsetz, H., \& Lehn, K. (1985). The structure of corporate ownership: Causes and consequences. Journal of Political Economy, 93(6), 1155-1177.

Dodd, P., \& Warner, J. (1983). On corporate governance: A study of proxy contests. Journal of Financial Economics, 11, 401-439.

Dukeminier, J., \& Krier, J. E. (2003). The rise of the perpetual trust. UCLA Law Review, 50, 1303-1344.

Dunn, M. (1980). The family office as a coordinating mechanism within the ruling class. Critical Sociology, 9, 8-23.

Easterbrook, F. H., \& Fishel, D. R. (1993). Contract and fiduciary duty. Journal of Law and Economics, April, 425-446.

Economist. (2014). America's elite: An heriditary meritocracy. January 24. Accessed via http://www.economist.com/news/briefing/21640316-children-rich-and-powerful-are-increasinglywell-suited-earning-wealth-and-power? .

Eddleston, K. A., \& Kellermanns, F. W. (2007). Destructive and productive family relationships: A stewardship theory perspective. Journal of Business Venturing, 22(4), 545-565.

Ellul, A., Pagano, M., \& Panunzi, F. (2010). Inheritance law and investment in family firms. American Economic Review, 100(5), 2414-2450.

Flanagan, J., Hamilton, S., Lincoln, D., Nichols, A., Ottum, L., \& Weber, J. (2011). Taking care of business: Case examples of separating personal wealth management from the family business. London (UK): Family Office Exchange (FOX).

Foley, C. F., \& Greenwood, R. (2010). The evolution of corporate ownership after IPO: The impact of investor protection. Review of Financial Studies, 23, 1231-1260.

Franks, J., Mayer, C., Volpin, P., \& Wagner, H. F. (2012). The life cycle of family ownership: International evidence. Review of Financial Studies, 25(6), 1675-1712.

Friedman, L. M. (1964). The dynastic trust. Yale Law Journal, 73(4), 547-592.

Gedajlovic, E., Carney, M., Chrisman, J. J., \& Kellermanns, F. W. (2012). The adolescence of family firm research taking stock and planning for the future. Journal of Management, 38(4), 1010-1037.

Gersick, K. E., Davis, J. A., McCollom Hampton, M., \& Lansberg, I. (1997). Generation to generation: Life cycles of the family business. Boston, MA: Harvard Business School Press.

Gilding, M. (2005). Families and fortunes: Accumulation, management succession and inheritance in wealthy families. Journal of Sociology, 41(1), 29-45.

Gomez-Mejia, L. R., Cruz, C., Berrone, P., \& De Castro, J. (2011). The bind that ties: Socioemotional wealth preservation in family firms. Academy of Management Annals, 5(1), 653-707.

Gray, L. P. (2005). How family dynamics influence the strucutre of the family office. Journal of Wealth Management, 8(2), 9-17.

Habbershon, T. G., \& Pistrui, J. (2002). Enterprising families domain: Family-influenced ownership groups in pursuit of transgenerational wealth. Family Business Review, 15(3), 223-237. 
Hansmann, H., \& Mattei, U. (1998). The functions of trust law: a comparative legal and economic analysis. N.Y.U. Law Review, May, 434-479.

Hawley, J., \& Williams, A. (2000). The rise of fiduciary capitalism: How institutional investors can make corporate America more democratic. Philadelphia: University of Pennsylvania Press.

Hiebl, M. R. (2014). A finance professional who understands the family: family firms' specific requirements for non-family chief financial officers. Review of Managerial Science, 8(4), 465494.

Hoy, F., \& Sharma, P. (2009). Entrepreneurial Family Firms. Upper Saddle River, NJ: Prentice Hall.

Jensen, M. C., \& Meckling, W. H. (1976). Theory of the firm: Managerial behavior, agency costs and ownership structure. Journal of Financial Economics, 3(4), 305-360.

Kellermanns, F. W., \& Eddleston, K. A. (2004). Feuding families: When conflict does a family firm good. Entrepreneurship Theory and Practice, 28(3), 209-228.

Kets de Vries, M. F. (1993). The dynamics of family controlled firms: The good and the bad news. Organizational Dynamics, 21(3), 59-71.

Kidwell, R., Kellermanns, F., \& Eddleston, K. (2012). Harmony, justice, confusion, and conflict in family firms: Implications for ethical climate and the "Fredo Effect". Journal of Business Ethics, 106(4), 503-517.

La Porta, R., Lopez-de-Silanes, F., Shleifer, A., \& Vishny, R. (1998). Law and finance. Journal of Political Economy, 106, 1133-1155.

La Porta, R., Lopez-de-Silanes, F., Shleifer, A., \& Vishny, R. (2000). Investor protection and corporate governance. Journal of Financial Economics, 58, 3-27.

La Porta, R., Lopez-De-Silanes, F., Shleifer, A., \& Vishny, R. (2002). Investor protection and corporate valuation. Journal of Finance, 57(3), 1147-1170.

Lan, L. L., \& Heracleous, L. (2010). Rethinking agency theory: The view from law. Academy of Management Review, 35(2), 294-314.

Lang, L. H. P., \& Stulz, R. (1994). Tobin's Q, corporate diversification, and firm performance. Journal of Political Economy, 102(6), 1248-1280.

Langbein, J. H. (1997). The secret life of the trust: The trust as an instrument of commerce. Yale Law Journal, 107, 165-189.

Langbein, J. H. (2005). Questioning the trust law duty of loyalty: Sole interest or best interest. Yale Law Journal, 114, 929-990.

Langbein, J. H., \& Posner, R. A. (1976). The revolution in trust investment law. American Bar Association Journal, 62, 887-891.

Lubatkin, L. H., Lane, P. J., \& Schulze, W. S. (2001). Agency relationships in firm governance. In M. A. Hitt, R. E. Freeman, \& J. R. Harrison (Eds.), Handbook of Strategic Management. Oxford, U.K.: Blackwell Publishing.

Luo, X., \& Chung, C. N. (2005). Keeping it all in the family: The role of particularistic relationships in business group performance during institutional transition. Administrative Science Quarterly, 50(3), 404-439.

Marcus, G. E. (1991). Law in the development of dynastic families among American business elites: The domestication of capital and the capitalization of family. Family Business Review, 4(1), 75-111.

Marcus, G. E., \& Hall, P. D. (1992). Lives in trust: The fortunes of dynastic families in late twentiethcentury America. Boulder, CO: Westview.

Michael-Tsabari, N., Labaki, R., \& Kay Zachari, R. (2014). The cluster paradigm updating the circles paradigm: The family firm and entrepreneurial activities across generations. Family Business Review, 27, 161-185.

Morck, R., Strangeland, D., \& Yeung, B. (2000). Inherited wealth, corporate control and economic growth: The Canadian disease. In R. K. Morck (Ed.), Concentrated Corporate Ownership. Chicago, IL.: University of Chicago Press.

Morck, R., \& Yeung, B. (2003). Agency problems in large family business groups. Entrepreneurship Theory and Practice, 27(4), 367-382. 
Nordqvist, M., \& Melin, L. (2010). Entrepreneurial families and family firms. Entrepreneurship \& Regional Development, 22(3), 1-29.

Obstfeld, D. (2005). Social networks, the tertius iungens orientation, and involvement in innovation. Administrative Science Quarterly, 50(1), 100-130.

Peng, M. W., \& Jiang, Y. (2010). Institutions behind family ownership and control in large firms. Journal of Management Studies, 47(2), 253-273.

Piketty, T. (2014). Capital in the 21 st century. Cambridge, MA, US: Belknap, Harvard University Press.

Reay, T., Pearson, A., \& Dyer, G. (2013). Advising family enterprise: Examining the role of family firm advisors. Family Business Review, 26(3), 209-215.

Rosplock, K. (2013). The complete family office handbook: A guide for affluent families and the advisors who serve them. New York: Bloomberg Financial.

Salvato, C., \& Corbetta, G. (2013). Transitional leadership of advisors as a facilitator of successors' leadership Construction. Family Business Review, 26(3), 235-254.

Schanzenbach, M. M., \& Sitkoff, R. H. (2006). Perptuities or taxes: Explaining the rise of the perpetual trust. Cardozo Law Review, 27, 2465-2509.

Schulze, W. S., Lubatkin, M. H., \& Dino, R. N. (2003). Exploring the agency consequences of ownership dispersion among the directors of private family firm. Academy of Management Journal, 46(2), 179-194.

Schulze, W. S., Lubatkin, M. H., Dino, R. N., \& Buchholtz, A. K. (2001). Agency relationships in family firms: Theory and evidence. Organization Science, 12(2), 99-116.

Sieger, P.; Zellweger, T. (2013). Entrepreneurial families: From a family enterprise to an entrepreneurial family. Zurich, Switzerland: Credit Suisse AG.

Sieger, P., Zellweger, T., Nason, R., \& Clinton, E. (2011). Portfolio entrepreneurship in family firms: A resource-based perspective. Strategic Entrepreneurship Journal, 5(4), 327-351.

Sitkoff, R. H. (2004). An agency costs theory of trust law. Cornell Law Review, 69, 621-684.

Strike, V. M. (2012). Advising the family firm: Reviewing the past to build the future. Family Business Review, 25(2), 156-177.

Strike, V. M. (2013). The most trusted advisor and the subtle advice process in family firms. Family Business Review, 26(3), 293-313.

Varian, H. (1990). Monitoring agents with other agents. Journal of Institutional and Theoretical Economics, 146, 153-174.

Ward, J., \& Aronoff, C. (2010). Family business governance: Maximizing family and business potential Marietta, GA: Business Owner Resources.

Weber, M. (1978). Economy and Society. Berkeley: University of California Press.

Welsh, D., Memili, E., Rosplock, K., Roure, J., \& Segurado, J. (2013). Perceptions of entrepreneurship across generations in family offices: A stewardship theory perspective. Journal of Family Business Strategy, 4(3), 213-226.

Wessel, S., Decker, C., Lange, K. S. G., \& Hack, A. (forthcoming). One size does not fit all: Entrepreneurial families' reliance on family offices. European Management Journal.

Wiseman, R. M., \& Gómez-Mejía, L. R. (1998). A behavioral agency model of managerial risk taking. Academy of Management Review, 23(1), 133-153.

Zeitlin, M. (1974). Corporate ownership and control: The large corporation and the capitalist class. American Journal of Sociology, 79(5), 1073-1118.

Zellweger, T. M., \& Kammerlander, N. (2014). Family Business Groups in Deutschland: Generationenübergreifendes Unternehmertum in grossen deutschen Unternehmerdynastien. St. Gallen, Switzerland: Center for Family Business at the University of St Gallen.

Zellweger, T. M., Kellermanns, F. W., Chrisman, J. J., \& Chua, J. H. (2012). Family control and family firm valuations by family CEOs: The importance of intentions for transgenerational control. Organization Science, 23(3), 851-868.

Zellweger, T. M., Nason, R., \& Nordqvist, M. (2012). From longevity of firms to transgenerational entrepreneurship of families. Family Business Review, 25(2), 136-155. 


\section{Table 1: Agency Conflicts in Family Business Governance}

\begin{tabular}{|l|l|}
\hline Type of conflict & Description of resulting costs \\
\hline $\begin{array}{l}\text { Principal-agent conflict, } \\
\text { owing to diverging } \\
\text { interest }\end{array}$ & $\begin{array}{l}\text { Agency costs to incentivize and monitor the agent to ensure that } \\
\text { he/she acts in the principal's interests }\end{array}$ \\
\hline $\begin{array}{l}\text { Principal-agent conflict, } \\
\text { owing to altruism }\end{array}$ & $\begin{array}{l}\text { Agency costs to incentivize and monitor the family agent because } \\
\text { altruism creates free-riding opportunities for family agents }\end{array}$ \\
\hline $\begin{array}{l}\text { Majority-minority-owner } \\
\text { conflict }\end{array}$ & $\begin{array}{l}\text { Agency costs from a majority (family) blockholder expropriating } \\
\text { nonfamily minority owners }\end{array}$ \\
\hline $\begin{array}{l}\text { Family blockholder } \\
\text { conflict }\end{array}$ & $\begin{array}{l}\text { Agency costs from aligning heterogeneous interests among family } \\
\text { blockholders }\end{array}$ \\
\hline Double-agency conflict & $\begin{array}{l}\text { Agency costs from aligning interests of agents monitoring other } \\
\text { agents from the double separation of ownership and control }\end{array}$ \\
\hline
\end{tabular}

Figure 1: Separation of Family and Assets: Resulting Family Blockholder and Doubleagency Costs

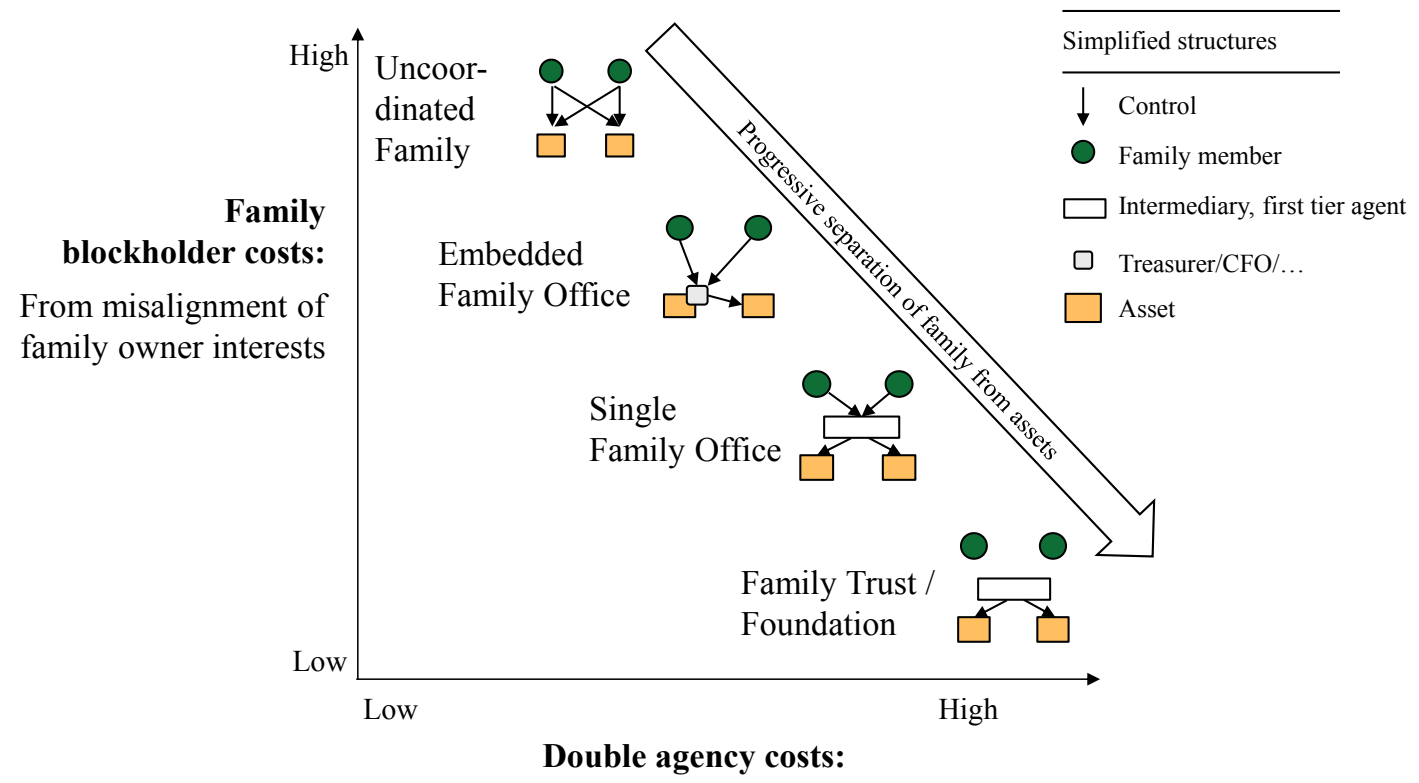

From deference to intermediary, establishment of first tier agent 


\section{Table 2: Governance Constellations to Manage Family Wealth}

\begin{tabular}{|c|c|c|c|c|}
\hline & Uncoordinated family & Embedded family office & Single family office & Family trust/foundation \\
\hline Tier structure & Two tier & Hybrid two tier & Three tier (dissolvable) & Three tier (entombed) \\
\hline $\begin{array}{l}\text { Separation of family } \\
\text { and wealth }\end{array}$ & No & Limited & High & Very high \\
\hline Discretion of fiduciary & N/A (no fiduciary) & Low & Medium & High \\
\hline Motives for setup & $\begin{array}{l}\text { Presence of strong } \\
\text { patriarch/matriarch, } \\
\text { privacy concerns, desire } \\
\text { to minimize costs for } \\
\text { institutionalization }\end{array}$ & $\begin{array}{l}\text { Presence of trusted fiduciary, desire } \\
\text { for cost-efficient and convenient } \\
\text { management }\end{array}$ & $\begin{array}{l}\text { Desire to professionalize wealth } \\
\text { management, desire to regulate } \\
\text { access to family wealth, economies } \\
\text { of scale and tax minimization }\end{array}$ & $\begin{array}{l}\text { Desire for legacy building, desire to } \\
\text { protect wealth from children, and } \\
\text { vice versa, tax minimization }\end{array}$ \\
\hline $\begin{array}{l}\text { Family blockholder } \\
\text { costs }\end{array}$ & $\begin{array}{l}\text { High: dispute over } \\
\text { wealth distribution, race } \\
\text { to the bottom over the } \\
\text { family's resources }\end{array}$ & $\begin{array}{l}\text { Only partly addressed: family } \\
\text { officer mainly takes care of private } \\
\text { financial matters, but not business } \\
\text { related matters }\end{array}$ & $\begin{array}{l}\text { Low: family office serves as a } \\
\text { unifying force }\end{array}$ & $\begin{array}{l}\text { Very low: strongly restricted access } \\
\text { of beneficiaries to wealth }\end{array}$ \\
\hline Double-agency costs & Nonexistent & $\begin{array}{l}\text { Emerging: with information access } \\
\text { and management of private family } \\
\text { wealth }\end{array}$ & $\begin{array}{l}\text { High: dealings between family } \\
\text { officer and second-tier agent very } \\
\text { difficult to monitor }\end{array}$ & $\begin{array}{l}\text { Very high: many opportunities for } \\
\text { self-dealing, second-tier agent } \\
\text { acquiesce in self-dealing with trustee }\end{array}$ \\
\hline Further costs & $\begin{array}{l}\text { Forgone economies of } \\
\text { scale and knowledge } \\
\text { advantages }\end{array}$ & $\begin{array}{l}\text { Majority-minority-owner/creditor } \\
\text { agency costs: private expenses paid } \\
\text { by company, ambiguous } \\
\text { governance } \\
\text { Inefficiencies based on potential } \\
\text { lack of competence of the fiduciary }\end{array}$ & $\begin{array}{l}\text { Costs for institutionalization: e.g., } \\
\text { hiring, incentivizing, and } \\
\text { monitoring of family officer, costs } \\
\text { for infrastructure }\end{array}$ & $\begin{array}{l}\text { Settlor-/Beneficiary-trustee agency } \\
\text { costs: self-dealing, trustee as } \\
\text { "manager without owners," limited } \\
\text { opportunity for incentives and } \\
\text { monitoring, unlikely to get caught } \\
\text { Costs for institutionalization: e.g., } \\
\text { hiring of trustee, infrastructure }\end{array}$ \\
\hline Contingency effects & $\begin{array}{l}\text { Blockholder conflicts } \\
\text { mitigated in presence of } \\
\text { family patriarch/ } \\
\text { matriarch or will and if } \\
\text { performance is } \\
\text { satisfactory }\end{array}$ & $\begin{array}{l}\text { Double-agency costs increases with } \\
\text { proportion of wealth managed by } \\
\text { fiduciary }\end{array}$ & $\begin{array}{l}\text { Doubly-agency costs depend on } \\
\text { power distribution of family and } \\
\text { fiduciary (e.g., monitoring power, } \\
\text { incentives of family officer) }\end{array}$ & $\begin{array}{l}\text { Agency costs increased when settlor } \\
\text { is incapacitated; agency costs } \\
\text { increased if structure is opaque }\end{array}$ \\
\hline Stability of structure & Instable & Rather stable & Stable & Very stable \\
\hline $\begin{array}{l}\text { Distributive effect for } \\
\text { family wealth over } \\
\text { time }\end{array}$ & $\begin{array}{l}\text { Rapidly dissolved and } \\
\text { distributed to individual } \\
\text { family members }\end{array}$ & $\begin{array}{l}\text { Kept together, but with the threat } \\
\text { that decisions are based on family- } \\
\text { political rationality }\end{array}$ & $\begin{array}{l}\text { Kept together, but at significant } \\
\text { governance and administrative } \\
\text { costs }\end{array}$ & $\begin{array}{l}\text { Kept together, but at significant } \\
\text { agency costs, risk aversion, gradual } \\
\text { depletion of wealth over time }\end{array}$ \\
\hline
\end{tabular}

